\title{
Species of thrips (Insecta, Thysanoptera) in two strawberry production systems in Rio Grande do Sul State, Brazil
}

\author{
Silvia M. J. Pinent ${ }^{1}$, Aline Nondillo ${ }^{1}$, Marcos Botton ${ }^{2}$, Luiza R. Redaelli ${ }^{1} \&$ Carlos E. da C. Pinent ${ }^{3}$
}

\begin{abstract}
'Programa de Pós-graduação em Fitotecnia, Departamento de Fitossanidade, Universidade Federal do Rio Grande do Sul, Avenida Bento Gonçalves 7712,91540-000 Porto Alegre-RS, Brasil.silviapi@portoweb.com.br; alinondillo@yahoo.com.br; luredael@ufrgs.br

${ }^{2}$ Embrapa Uva e Vinho, Rua Livramento 515, Caixa Postal 130, 95700-000 Bento Gonçalves-RS, Brasil. marcos@cnpuv.embrapa.br

${ }^{3}$ Departamento de Estatística, Centro de Ciências Exatas e Tecnologia da Universidade de Caxias do Sul, Rua Francisco Getúlio Vargas, 1130, 95070-560 Caxias do Sul-RS, Brasil. carlospi@portoweb.com.br
\end{abstract}

\begin{abstract}
Species of thrips (Insecta, Thysanoptera) in two strawberry production systems in Rio Grande do Sul, Brazil. Thrips are tiny insects responsible for the reduction of strawberry fruit quality. The work aimed to record and quantify the thysanopterofauna present in two strawberry production systems, low tunnel and semi-hydroponic. Leaves, flowers and fruits were collected weekly, from July 2005 to December 2006 in Caxias do Sul and Bom Princípio municipalities, RS. A total of 664 individuals were collected, representing two families, four genus and 10 species: Frankliniella occidentalis (Pergande, 1895), F. schultzei (Trybom, 1910), F. rodeos Moulton, 1933, F. simplex (Priesner, 1924), F. williamsi (Hood, 1915), F. gemina (Bagnall, 1919), Frankliniella sp., Thrips tabaci (Lindeman, 1888), Thrips tabaci (Lindeman, 1888), Caliothrips fasciatus (Pergande 1895) from Thripidae and Heterothrips sp. from Heterothripidae. Frankliniella occidentalis represented $89.7 \%$ of the samples with $95.8 \%$ of the species collected in flowers, $3.9 \%$ in fruits and $0.8 \%$ in leaves. The results show that flowers are the most important food resource for these insects on strawberry plants. Frankliniella rodeos, F. simplex, F. williamsi, C. fasciatus, and Heterothrips sp. are new records on strawberry for Brazil.
\end{abstract}

KEYWORDS. Fragaria x ananassa; species survey; thysanopterans.

RESUMO. Espécies de tripes (Insecta, Thysanoptera) associadas à cultura do morangueiro em dois sistemas de produção no Rio Grande do Sul, Brasil. Tripes são insetos diminutos responsáveis pela redução da qualidade dos frutos do morangueiro. O trabalho objetivou registrar e quantificar a tisanopterofauna presente em dois sistemas de produção de morangueiro, túnel baixo e semihidropônico. Folhas, flores e frutos foram coletados semanalmente, de julho de 2005 a dezembro de 2006 em Caxias do Sul e Bom Princípio, RS. Foram coletados 664 indivíduos pertencentes a duas famílias, quatro gêneros e 10 espécies: Frankliniella occidentalis (Pergande, 1895), F. schultzei (Trybom, 1910), F. rodeos (Moulton, 1933), F. simplex (Priesner, 1924), F. williamsi (Hood, 1915), F. gemina (Bagnall, 1919), Frankliniella sp., Thrips tabaci (Lindeman, 1888) e Caliothrips fasciatus (Pergande, 1895) pertencentes a Thripidae, e Heterothrips sp. pertencente a Heterothripidae. Com 593 ocorrências, F. occidentalis representou 89,3\% dos insetos coletados, com $87,9 \%$ dos indivíduos nas flores, $8,4 \%$ nas folhas e 3,7\% nos frutos. Os resultados sugerem que as flores do morangueiro representam o recurso preferido pelos tripes. Frankliniella rodeos, F. simplex, F. williamsi, C. fasciatus e Heterothrips sp. são novos registros na cultura para o Brasil.

PALAVRAS-CHAVE. Fragaria $\mathrm{x}$ ananassa; levantamento de espécies; tisanópteros.

Strawberries (Fragaria x ananassa Duchesne) (Rosaceae) are commercially produced in several countries such as France, Spain, United Kingdom, Germany, Poland, United States, Mexico, Guatemala, Ecuador, Chile, Argentina and Brazil, especially due to the attraction exerted by their red and aromatic fruits (Vieira 2001; Coll et al. 2006).

In Brazil, the area grown with strawberry is estimated in 3,500 ha, located mainly in the states of Minas Gerais (41.4\%), Rio Grande do Sul (25.6\%), São Paulo (15.4\%), Paraná (4.7\%), and Federal District (4\%) (Calvete et al. 2005). In Rio Grande do Sul (RS), the area grown with strawberries is of 700 ha. The crop is grown mainly in low tunnel and more recently in a semi-hydroponic system (Emater 2004; Embrapa 2007). In the low tunnel system the seedlings are planted in the soil using beds covered with plastic and sustained by galvanized iron arches, forming a tunnel which main function is to protect the plants from rain, frost, UV rays, and to reduce the spread of pests and diseases (Embrapa 2005). The semi-hydroponic system is derived from the hydroponics system and is conducted inside plastic or glass greenhouses, and the plants are kept in shelves located at different heights (Embrapa 2007).

Several species of Thysanoptera infest strawberry plants reducing fruit quality in several countries, being spread mainly by plant commerce (Coll et al. 2006; Ripa et al. 2009). Moreover, the control of thrips in infested areas is not easy due to their small size, rapid population growth and cryptic habits that include polyphagy and parthenogenesis (Coll et al. 2006; Mound 2007).

The order Thysanoptera comprehends approximately 5,800 species, but only $1 \%$ causes economic losses in commercial crops (Mound \& Marullo 1996; Mound 2007). The damage caused by thrips is due to lesions on plant tissue produced by the bite-sucking mouth-parts and by the transmission of pathogens (Mound \& Kibby 1998; Moritz et al. 2004). 
Several species are associated with strawberry crops in Australia, according to Steiner \& Goodwin (2005). These authors recorded Frankliniella occidentalis (Pergande, 1895), Frankliniella intonsa (Trybom, 1895), Frankliniella tritici (Fitch, 1855), Thrips atratus (Haliday, 1836), Thrips major (Uzel, 1895), Thrips tabaci (Lindeman, 1888), Thrips fuscipennis (Haliday, 1836), Thrips imaginis (Bagnal, 1926), and Scirtothrips dorsalis (Hood, 1919). In Florida, USA, according to Mass (1998), the more important species damaging strawberry plants are Frankliniella tritici (Fitch) and Frankliniella bispinosa (Morgan, 1913). In California, F. occidentalis is the prevalent species feeding on strawberry blossoms and causing the stigmas and anthers to turn brown and wither prematurely (UC IPM 2008). In Italy, Marullo \& Tremblay (1993) mention F. intonsa and F. occidentalis as highly polyphagous species, having the strawberry as a host plant. The damage attributed to these species is the distortion and atrophy of the fruit, caused by insect's feeding on the flowers. In Brazil these injuries were studied by Nondillo et al. (2010). In Spain, Israel and Turkey, F. occidentalis is also reported to cause damage in strawberry flowers. In Turkey, among 14 identified species, F. occidentalis was the dominant specie with $97 \%$ of insect collected (GonzálesZamora \& Garcia-Marí 2003; Coll et al. 2006; Atakan 2008).

In Brazil there is lack of information about the main species of thrips associated with strawberry plants especially in different production systems. In the state of Rio Grande do Sul few studies emphasize the thysanopterans on this crop. Thus, the main goal of this research was to identify and quantify thrips species associated with strawberry crops in low tunnel and semi-hydroponics systems in Rio Grande do Sul.

\section{MATERIAL AND METHODS}

Between July 2005 and December 2006, weekly samplings were carried out in three commercial strawberry fields cultivar Aromas, being two developed in low tunnel systems (areas A1 and A2), located in Souza Farm, Caxias do Sul municipality $\left(29^{\circ} 10^{\prime} \mathrm{S}, 51^{\circ} 10^{\prime} \mathrm{W}\right)$ and one in semi-hydroponic system (area A3), located in Bom Princípio municipality

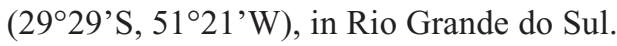

The areas A1 and A2, measuring $114 \mathrm{~m} \times 70 \mathrm{~m}$ each, had 71 beds of $70 \mathrm{~m}$ in length and $1 \mathrm{~m}$ in width, each with two rows of plants disposed at a distance of $35 \mathrm{~cm}$ between rows and $27 \mathrm{~cm}$ between plants, with a total of 518 seedlings. In each area, ten sampling stations were established with a ray of $1 \mathrm{~m}$ for sampling purposes. A3 had $520 \mathrm{~m}^{2}$, and 5,000 seedlings distributed in 22 benches of $40 \mathrm{~m} \times 13 \mathrm{~m}$ each, with two rows of plants, with 114 seedlings/bench. In this area, ten sampling stations with a ray of $0.70 \mathrm{~m}$ were established.

From the planting date until the end of the second phenological cycle of the culture, samples were taken, collecting randomly one leaf, one flower and one fruit in each station from the same plant that were placed individually in plastic bags and taken to the laboratory. Flowers were collected when they were completely opened.
In the Entomology Laboratory of Embrapa Uva e Vinho in Bento Gonçalves, RS, adult and immature thrips were separated from the plants using a thin brush under stereomicroscope and placed in AGA (10 parts of ethylic alcohol $60 \%$, one part of glacial acetic acid and one part of glycerin). In the Biology, Ecology and Biological Insect Control laboratory at the Federal University of Rio Grande do Sul (UFRGS), adults were mounted on microscopy slides according to Mound \& Kibby (1998) and Moritz et al. (2004), and identified using specialized keys.

The number of individuals per area, plant part, sex, and species were recorded using a spread sheet of the statistical program SPSS. The data was subjected to descriptive analyses. The faunal index was based on the relative abundance (RA) according to the standard convention: rare if $\mathrm{RA} \leqslant 0.01$, intermediate if $0.1 \leqslant \mathrm{RA}<0.01$ and abundant if $\mathrm{RA}>0.1$.

Thrips specimens were deposited in the reference collection of Bioecolab/UFRGS and in the Entomology Laboratory of Embrapa Uva e Vinho, RS.

\section{RESULTS AND DISCUSSION}

A total of 982 individuals were collected between July 2005 and December 2006 in the three sampling areas. From these, $318(47.9 \%)$ were immature individuals and 664 $(52.1 \%)$ were adults. Among the adults, 517 (77.9\%) were females and $147(22.1 \%)$ were males. Immature individuals were more abundant in flowers, $304(95.6 \%)$, than in fruits, $14(4.4 \%)$. Immature individuals were not identified due to the lack of identification keys for this stage, particularly for Neotropical species. Identification keys are available only for adult females according to Moritz et al. (2007). However, the presence of larval instars, pre-pupae, pupae and eggs, generally on the underside of the sepals, characterizes the strawberry as a suitable host plant, a criterion adopted by Pinent et al. (2005). However, factors determining reproductive host plant for the thrips are not yet understood or poorly defined (Ripa et al. 2009).

Ten species of thrips were identified belonging to four genera and two families. In the family Thripidae were identified: F. occidentalis, Frankliniella schultzei (Trybom, 1910), T. tabaci, Frankliniella rodeos (Moulton, 1933), Frankliniella simplex (Priesner, 1924), Frankliniella williamsi (Hood, 1915), Frankliniella gemina (Bagnall, 1919), Frankliniella sp., and Caliothrips fasciatus (Pergande, 1895). The family Heterothripidae was represented by Heterothrips sp.

The species F. occidentalis, with 593 records, represented $89.3 \%$ of all samples, with $95.8 \%$ collected in flowers, $8.4 \%$ in the leaves, and $3.7 \%$ in the fruits. Only F. occidentalis and $F$. rodeos occurred in the three areas, with the former being more abundant in the low tunnel systems A1 and A2, representing, respectively, $47.2 \%$ and $44.2 \%$, and in the semi-hydroponic A3, 8.6\% (Table I).

Considering abundance of thrips in the three areas, $F$. occidentalis was the dominant species (relative frequency above $10 \%$ ). F. schultzei, F. rodeos, and T. tabaci were inter- 
Table I. Number and relative frequency of thrips species sampled on leaves, flowers, and fruits of strawberry, cultivar Aromas, cropped in low tunnel system (A1 and A2), Caxias do Sul municipality, and semi-hydroponics system (A3), Bom Princípio municipality, in the state of Rio Grande do Sul, Brazil, from July/2005 to December/2006.

\begin{tabular}{|c|c|c|c|c|c|c|c|c|c|c|c|c|c|c|c|c|c|c|}
\hline \multirow{3}{*}{ Family/Species } & \multicolumn{6}{|c|}{ A1 } & \multicolumn{6}{|c|}{ A2 } & \multicolumn{6}{|c|}{ A3 } \\
\hline & \multicolumn{2}{|c|}{ Leaf } & \multicolumn{2}{|c|}{ Flower } & \multicolumn{2}{|c|}{ Fruit } & \multicolumn{2}{|c|}{ Leaf } & \multicolumn{2}{|c|}{ Flower } & \multicolumn{2}{|c|}{ Fruit } & \multicolumn{2}{|c|}{ Leaf } & \multicolumn{2}{|c|}{ Flower } & \multicolumn{2}{|c|}{ Fruit } \\
\hline & $\mathrm{n}$ & $\%$ & $\mathrm{n}$ & $\%$ & $\mathrm{n}$ & $\%$ & $\mathrm{n}$ & $\%$ & $\mathrm{n}$ & $\%$ & $\mathrm{n}$ & $\%$ & $\mathrm{n}$ & $\%$ & $\mathrm{n}$ & $\%$ & $\mathrm{n}$ & $\%$ \\
\hline \multicolumn{19}{|l|}{ Thripidae } \\
\hline Frankliniella occidentalis & 0 & 0 & 268 & 95.7 & 12 & 4.3 & 1 & 0.4 & 253 & 96.6 & 8 & 3.0 & 49 & 96.1 & 0 & 0 & 2 & 3.9 \\
\hline Frankliniella schultzei & 0 & 0 & 2 & 100 & 0 & 0 & 0 & 0 & 0 & 0 & 0 & 0 & 0 & 0 & 31 & 100 & 0 & 0 \\
\hline Thrips tabaci & 0 & 0 & 6 & 85.7 & 1 & 14.3 & 0 & 0 & 6 & 75 & 2 & 25 & 0 & 0 & 0 & 0 & 0 & 0 \\
\hline Franklinella rodeos & 0 & 0 & 2 & 100 & 0 & 0 & 0 & 0 & 3 & 100 & 0 & 0 & 0 & 0 & 4 & 100 & 0 & 0 \\
\hline Franklinella simplex & 0 & 0 & 2 & 100 & 0 & 0 & 0 & 0 & 2 & 100 & 0 & 0 & 0 & 0 & 4 & 0 & 0 & 0 \\
\hline Franklinella williamsi & 0 & 0 & 0 & 0 & 0 & 0 & 0 & 0 & 0 & 0 & 0 & 0 & 0 & 0 & 2 & 100 & 0 & 0 \\
\hline Caliothrips fasciatus & 0 & 0 & 0 & 0 & 0 & 0 & 0 & 0 & 0 & 0 & 0 & 0 & 1 & 100 & 0 & 0 & 0 & 0 \\
\hline Franklinella gemina & 0 & 0 & 0 & 0 & 0 & 0 & 0 & 0 & 1 & 100 & 0 & 0 & 0 & 0 & 0 & 0 & 0 & 0 \\
\hline Franklinella sp. & 0 & 0 & 0 & 0 & 0 & 0 & 0 & 0 & 1 & 100 & 0 & 0 & 0 & 0 & 0 & 0 & 0 & 0 \\
\hline \multicolumn{19}{|l|}{ Heterothripidae } \\
\hline Heterothrips sp. & 0 & 0 & 1 & 100 & 0 & 0 & 0 & 0 & 0 & 0 & 0 & 0 & 0 & 0 & 0 & 0 & 0 & 0 \\
\hline Total & 0 & & 281 & & 13 & & 1 & & 266 & & 10 & & 50 & & 41 & & 2 & \\
\hline
\end{tabular}

mediate (relative frequency between $10 \%$ and $1 \%$ ) with the other species considered rare (relative frequency below 1\%) (Pinent et al. 2006).

Analyzing the distribution pattern of these thrips species related to cropping systems, we observed that in the low tunnel A1, F. occidentalis was the dominant species and T. tabaci was the intermediate, while F. schultzei, F. rodeos, and Heterothrips sp. were rare. In the area A2, F. occidentalis was also the dominant species, with $F$. rodeos and $T$. tabaci intermediate, while $F$. gemina, $F$. simplex and $F$. sp. were rare. In the semi-hydroponic area $\mathrm{A} 3, F$. occidentalis and $F$. schultzei were dominant and $C$. fasciatus, $F$. rodeos, and $F$. williamsi intermediate, with no rare species. The knowledge of this distribution and frequency represents an important tool that indicates which species should be monitored and controlled in sampled areas.

Considering the micro-habitats, 588 specimens of thrips occurred in the flowers $(88.5 \%), 51$ in the leaves $(7.7 \%)$ and 25 in the fruits $(3.8 \%)$ (Table I). The most abundant species in flowers was F. occidentalis with $87.9 \%$ of individuals, $8.4 \%$ in leaves and $3.7 \%$ in fruits (Table I). The second most abundant species, F. schultzei, with 33 individuals recorded (5.0\%), occurred only in the flowers in both production systems, in areas A1 and A3. T. tabaci, with 14 occurrences (2.1\%), had 12 individuals in the flowers in areas A1 and A2 (85.7\%), and two individuals in the fruits in A2 (14.3\%). F. rodeos, $F$. simplex, F. williamsi, F. gemina, Frankliniella sp., and Heterothrips sp. were sampled in the flowers, with $C$. fasciatus being the only species collected in leaves of strawberry plant in addition to $F$. occidentalis (Table I).

The results suggest that the flowers of the strawberry plants constitute the major food resource for thrips. According to Kirk (1985), thrips on flowers are of particular interest because they feed during the pollination stage reducing fruit and seed production. This is still a controversial aspect and should be studied with more details because during feeding in the flowers the body of the thrips gets covered with pollen that is transported to other flowers while the insects move around. Mound (2005) concludes that the major advance in the studies of Thysanoptera is the fact that these insects are recognized as effective pollinators alone or in association with other organisms. In Brazil, there is a lack of studies on this subject, as pointed out by Calvete et al. (2005), especially for strawberry plants in protected environments.

Among the ten thrips species recorded in the present study, seven belong to the genus Frankliniella which is represented in Brazil by 41 species described by Monteiro et al. (2001). Even though the genus is well characterized, the identification is complex because the species $F$. gemina $(1.5 \mathrm{~mm}), F$. rodeos $(1.3 \mathrm{~mm})$, and $F$. williamsi $(1.1 \mathrm{~mm})$ are very similar in relation to body length and coloration (light yellow). Among these species only $F$. rodeos have economic importance. F. simplex, despite the phytophagous habit and feeding on several cultures or spontaneous growth plants, are not associated with significant plant damage (Monteiro et al. 2001; Cavalleri et al. 2006; Pinent et al. 2005, 2006).

Among the three most common thrips species in this study, F. occidentalis, originally from California and México, was the most abundant and is currently broadly distributed around the world (Moritz et al. 2004). Ripa et al. (2009) have been recording this species in Chile since 1992, where it is considered as an important pest on fruit and vegetable crops. In Uruguay, the introduction of this species represents a serious phytosanitary threat to the vines due to lesions caused by oviposition on developing fruits (Mujica et al. 2007). In Florida, USA, according to Mass (1998), the species 
Frankliniella bispinosa (Pergande) causes serious damage to strawberry crops, while F. occidentalis, although more abundant, rarely causes expressive damage. In Brazil, F. occidentalis is considered a pest of several cultures since 1993, especially on industrial cut flowers, such as chrysanthemum and roses (Monteiro et al. 1999). There are records of $F$. occidentalis in the states of Alagoas, Pernambuco, Rio de Janeiro, Rio Grande do Sul, and São Paulo (Monteiro et al. 2001). In São Paulo, this species was recorded tanning and deforming peach fruits (Pinent et al. 2008). In the present research, the damage caused to the strawberry plant results from feeding mainly on flowers causing tanned areas on stamens and flower receptacles. Damage on fruits has not been described in the literature, probably due to low frequency $(3.7 \%)$ of thrips on them, indicating that this is not a preferential food source. Nondillo et al. (2010) characterized the damage caused by $F$. occidentalis in flowers and fruits of strawberry of the same cultivar, concluding that $F$. occidentalis tans flowers and fruits, but is not responsible for deformations. Another species that deserves consideration is F. schultzei, broadly distributed in African and Asian countries, Australia, New Zealand and in the North, Central and South Americas, where it has been observed feeding on flowers, especially Asteraceae plants, and also on weeds that represent a good resource for the development of their populations (Moritz et al. 2007). Wilson et al. (1996) observed that specimens of F. schultzei are important predators of eggs of mites in cotton crops in some regions of Australia. In Brazil, according to Monteiro et al. (1999), F. schultzei preys on mites of the species Polyphagotarsonemus latus (Banks, 1904) (Acari, Tarsonemidae) and Tetranychus urticae (Koch, 1836) (Acari, Tetranychidae). In Paranapanema municipality, in the state of São Paulo, Pinent et al. (2008) observed F. schultzei damaging peach fruits. Pinent et al. (2007) recorded F. schultzei as the most abundant species on leaves, flowers and fruits of strawberry in Rio Grande do Sul. In the present work, the highest abundance of $F$. schultzei occurred in flowers from the semi-hydroponic system.

It is important also to mention the onion thrips, T. tabaci, originated probably from the east Mediterranean where, according to Monteiro et al. (1999), the onion, Allium cepa, Lineu (Liliaceae), is a native plant. T. tabaci is a common pest infesting several plants and feeding on larvae of other thrips and mites (Moritz et al. 2004). From a total of 280 species in this primitive genus of Thysanoptera, only four occur in Brazil (Monteiro et al. 2001). Mound (2005) considers that $T$. tabaci is losing its pest status because its population has decreased as well as its importance as vector of the tospovirus. In California, strawberry crops often have mixed colonies of thrips species including low percentage of T. tabaci (UC IPM 2008). This fact has also being observed in some strawberry production areas in Brazil. Pinent et al. (2007) recorded in Gaucho Highlands of Rio Grande do Sul small populations of T. tabaci in flowers of strawberry, representing only $2.5 \%$ of 356 specimens collected. In peach crops in Paranapanema, São Paulo, T. tabaci represented 7.0\% of a total of 115 individuals comprising seven species (Pinent et al. 2008). In the present study, only $1.9 \%$ of the individuals occurred in strawberry flowers.

The highest abundance of thrips was recorded in the low tunnel system, totalizing 294 (44.3\%) adult specimens in A1 and $277(41.7 \%)$ in A2. In the semi-hydroponic system (A3) $93(14.0 \%)$ thrips specimens were recorded.

Different factors may interfere in the frequency of species in relation to different production systems, among them the presence of other crops or weeds, since thrips are easily carried by the wind rather than flying. The presence and absence of natural enemies is a relevant, but poorly studied aspect, deserving attention in future works. The semi-hydroponic system is a protected environment that makes it difficult the entrance of insects. However, it was found the same richness (six species) in this system than in the low tunnel production. Among the species recorded in our investigation, only F. occidentalis and F. schultzei have economical importance for the strawberry crop. F. rodeos, F. simplex, $F$. williamsi, $C$. fasciatus, and Heterothrips sp. are new records on strawberry plants in Rio Grande do Sul and Brazil.

\section{ACKNOWLEDGEMENTS}

To the Conselho Nacional de Desenvolvimento Científico e Tecnológico (CNPq) for financial support (Process 473433/ 2006-0) and for grants to the four first authors.

\section{REFERENCES}

Atakan, E. 2008. Adana ve Mersin illerinde çilekte thrips (Thysanoptera) türleri ve zarar1 üzerine ön ara_t1rmalar. Turkish Journal of Entomology 39: 91-101.

Calvete, E. O.; H. C. Rocha \& O. T. Antunes. 2005. Morangueiro polinizado pela abelha jataí em ambiente protegido. Passo Fundo, UPF, 53 p.

Cavalleri, A.; H. P. Romanowski \& L. R. Redaelli. 2006. Thrips species (Insecta, Thysanoptera) inhabiting plants of the Parque Estadual de Itapuã, Viamão, Rio Grande do Sul State, Brasil. Revista Brasileira de Zoologia 23: 367-374.

Coll, M.; S. Shakya; I. Shouster \& Y. Nenner. 2006. Decision-making tools for Frankliniella occidentalis management in strawberry: consideration of target markets. Entomologia Experimentalis et Applicata 121: 1-9.

Emater. 2004. Levantamento da fruticultura comercial do Rio Grande do Sul - 2003/2004. Porto Alegre, Ascar Emater-RS, 89 p.

Embrapa. 2005. Sistema de produção de morangos para mesa na Região da Serra Gaúcha e Encosta Superior do Nordeste. Circular Técnica $n^{\circ} 6$, Bento Gonçalves, Available from: http://sistemasde producao.cnptia.embrapa.br/FontesHTML/Morango/MesaSerra Gaucha/index.htm (accessed 13th July 2010).

Embrapa. 2007. Produção de morangos no sistema semi-hidropônico. Circular Técnica ${ }^{\circ}$ 62, Bento Gonçalves, 23 p. Available from: http:// www.infoteca.cnptia.embrapa.br/bitstream/CNPUV/8140/1/cir062.pdf (accessed 13th July 2010).

Gonzáles-Zamora, J. E. \& F.Garcia-Marí. 2003. The efficiency of several sampling methods for Frankliniella occidentalis (Thysanoptera: Thripidae) in strawberry flowers. Journal of Applied Entomology 127: 516-521.

Kirk, W. D. J. 1985. Pollen-feeding and the host specificity and fecundity of flower thrips (Thysanoptera). Ecological Entomology 10: 281-289.

Marullo, R. \& E. Tremblay. 1993. Le specie italiane del genere Frankliniella Karny. Potenza, Informatore Fitopatologico 11: 37-44. 
Mass J. L. 1998. Compendium of strawberry diseases USDA. Maryland, APS Press, $98 \mathrm{p}$

Monteiro, R. C.; L. A. Mound \& R. A. Zucchi. 1999. Thrips (Thysanoptera) as pests of plants production in Brazil. Revista Brasileira de Entomologia 43: 163-171.

Monteiro, R. C.; L. A. Mound \& R. A. Zucchi. 2001. Espécies de Frankliniella (Thysanoptera: Thripidae) de importância agrícola no Brasil. Neotropical Entomology 30: 65-72.

Moritz, G. B; C. O’Donnell \& M. P. Parrella. 2007. Pest thrips of North America associated with domestic and imported crops. Queensland, CD-ROM CBIT Publishing.

Moritz, G. B.; L. A. Mound; D. C. Morris \& A. Goldarazena. 2004. Thrips ID: pest thrips of the world. An interactive identification and information system. Canberra, ACIAR. 1 CD-ROM.

Mound, L. A. 2005. Thysanoptera: diversity and interactions. Annual Review of Entomology 50: 247-269.

Mound, L. A. 2007. Thysanoptera (Thrips) of the World - a checklist. Available from: http://www.ento.csiro.au/thysanoptera/worldthrips.html (accessed 25th November 2008).

Mound, L. A. \& G. Kibby. 1998. Thysanoptera: An Identification Guide. $2^{\mathrm{a}}$ Edição, Wallinggford, CAB, $70 \mathrm{p}$.

Mound, L.A. \& R. Marullo. 1996. The thrips of Central and South America: an introduction (Insecta: Thysanoptera). Florida, Associated Publishers, $487 \mathrm{p}$.

Mujica, M. V.; I. Scatoni; J. Franco; S. Nuñez \& C. Bentancourt. 2007. Fluctuación poblacional de Frankliniella occidentalis (Pergande) (Thysanoptera: Thripidae) en Vitis vinifera L. cv. Italia en la zona sur de Uruguay. Boletin de Sanidad Vegetal 33: 457-467.

Nondillo, A.; L. R. Redaelli; S. M. J. Pinent \& M. Botton. 2010. Caracterização das injúrias causadas por Frankliniella occidentalis no morangueiro. Ciência Rural 40: 820-826.
Pinent, S. M. J.; H. P. Romanowski; L. R. Redaelli \& A. Cavalleri. 2005. Thysanoptera: plantas visitadas e hospedeiras no Parque Estadual de Itapuã, Vimão, RS, Brazil. Iheringia, Série Zoologia 95: 9-16.

Pinent, S. M. J.; H. P. Romanowski; L. R. Redaelli \& A. Cavalleri. 2006. Species composition and structure of Thysanoptera communities in different microhabitats at the Parque Estadual de Itapuã, Viamão, RS. Brazilian Journal of Biology 66: 765-779.

Pinent, S. M. J.; M. Botton \& L. R. Redaelli. 2007. Thrips species (Thysanoptera) on strawberry, persimmon and grape in the Gaúcho Highlands, Rio Grande do Sul State, Southern Brazil. Journal of Insect Science 7: 28 .

Pinent S. M. J.; M. Mascaro; M. Botton \& L. R. Redaelli. 2008. Thrips (Thysanoptera: Thripidae, Phlaeothripidae) damaging peach in Paranapanema, São Paulo State, Brasil. Neotropical Entomology 37: 486-488.

Ripa, R.; J. Funderburk; F. Rodriguez \& F. Espinoza. 2009. Population abundance of Frankliniella occidentalis (Pergande) (Thysanoptera: Thripidae) and natural enemies on plant hosts in Central Chile. Annals of the Entomological Society of America. 38: 333-344.

Steiner, M. Y. \& S. Goodwin. 2005. Management of thrips (Thysanoptera: Thripidae) in Australian strawberry crops: within-plant distribution characteristics and action threshold. Australian Journal of Entomology 44: 175-185.

UC IPM 2008: UC Management for Western Flower Thrips on Strawberry. [S.1.]: University of California, Available from: http://www.ipm. ucdavis.edu/PMG/r734301211.html (accessed 27th April 2010).

Vieira, F. C. 2001. A cultura do Morangueiro. Fruticultura. Available from: http://www.pa.esalq.usp.br/ pa1200/frut1200.htm (Accessed 16 $6^{\text {th }}$ January 2006).

Wilson, L. J.; L. R. Bauer \& G. H. Walter. 1996. Phytophagous thrips are predators of two spotted spider mites (Acari; Tetranychidae) on cotton in Australia. Bulletin of Entomological Research 86: 297-305.

Received 16/7/2010; accepted 3/8/201

Editor: Sonia Maria Noemberg Lázzari 